\title{
Painful Side of Flirting: Role of Parents' Education Level on Flirting Violence
}

\section{Rüçhan Gökdağ, Anadolu University, Turkey}

\begin{abstract}
Love is one of important needs that human beings meet to continue their lives. The reason is that people establish relationships with others to meet this need, and among these relationships, the love-based one is called flirting. The quality of these relationships determines whether this love will continue in future or not. Also, violence to be experienced in flirting is important to maintain the relationship. People are likely to be influenced by the structure of the society they belong to. In this respect, the family is a social unit, and it is important to remember that an individual shapes himself or herself within the family. An individual's violent attitudes are shaped within the family as well, and this is also the case for flirting violence. The violence that individuals were exposed to in the past is likely to be a sign of future probable violence. Therefore, individuals may reflect that violence upon his or her partner in the period of flirting. In line with the suggestions put forward in the researcher's previous studies on students' thoughts about flirting violence, it was considered to be necessary to investigate parents' education, which is thought to be likely to increase flirting violence. In this respect, the present study was carried out with 250 students taking the courses of psychology, developmental psychology, health communication, and communication within the family, which the researcher gave in associate degree, undergraduate and postgraduate programs at Anadolu University in the academic year of 2016-2017. The questions used in the study were distributed to the students in class, and they were asked to respond to the questions on voluntary basis. In the study, of all the students, 178 of them responded to the questions. In relation to the factors influential on the participants' views about the flirting process and about flirting violence, the relationship between their views and their parents' levels of education was examined. The questionnaire data were analyzed with Chi-Square test using the package software of SPSS. The results revealed that within the socio-cultural structure, the mother's education level was not significantly influential on flirtingviolence while the father's education level significantly triggered flirting violence.
\end{abstract}

Keywords Flirting, flirting violence, parents' education levels, violence 


\section{Introduction}

Thanks to their social relationships individuals have started establishing with their environment since birth, they develop themselves, become experienced and shape their behaviors. One of the most important needs that direct behaviors is the need for loving and being loved. According to the hierarchy of needs, loving and being loved follow the need for safety. In order to meet this need for love, sharing of love, which occurs regardless of the gender and of sexual tendency, is called flirting. What determines whether sharing of love will continue in future or not is the quality of the flirting relationship. Violence, which is likely to be experienced in a flirting relationship plays a very important role in whether to maintain or end that relationship (Gökdağ, 2017: 3). There are various factors determining the degree of the flirting violence in a society. Among these factors, the most important one is to what extent the society is conscious of the concept of violence and how individuals interpret it.

Related studies demonstrate that violence is shaped by the values in a society rather than being a biological phenomenon (Özcebe et.al., 2002: 20-28). Considering the fact that socialization begins and ends up with its final state to a considerable extent within the family, the role of the family in shaping violence behaviors cannot be ignored. According to Yumuşak and Şahin (2014: 233-252), an individual's violent attitudes are shaped within the family, and the causes of violence in the family are also true for flirting violence. Educational and financial differences between women and men that make the former dependent on the latter are also likely to lead to flirting violence.

In general, the causes of flirting violence include the following: The society views the men superior to the women; men's misbehaviors are tolerated more; and conventional judgements that are disadvantages for women (Aslan et.al., 2008: 49).An important factor regarding these negative attitudes that turn against women is the education level of individuals. Related studies point out that women with a high level of education are exposed to less violence. Ergin and colleagues (2005) found that illiterate women experience violence 2.6 times more than those who are educated or those who are graduates of a university (Cited in Tanriverdi and Şıpkın, 2008, p. 185). 
Human beings learn by doing. Children exposed to violence in their family are likely to experience inefficacy in their relationships with others and such behavioral problems as social discord and aggression in their future lives, and they tend to demonstrate violent behaviors at older ages (Rosen and Bezold, 1996: 521). The violent behavior exposed to or witnessed within the family is likely to be reflected upon the spouse in the period of flirting. Moreover, like violence in family, the flirting violence is a type of violence which is hard to intervene and which people experience in their private lives, try to cope with it on their own, and prefer to keep it as a secret.

The present study was carried out with 250 students from different faculties of Anadolu University in the academic year of 2016-2017 to determine their views about whether parents' levels of education are influential on flirting violence. In the study, the research problem included revealing the participants' views about whether parents' levels of education are influential on flirting violence.

\section{Purpose of the Study}

The purpose of the study was to determine university students' views about whether parents' levels of education are influential on flirting violence.

The present study is thought to an original one since it tried to reveal whether parents' levels of education constitute a factor responsible for the gradual spread of flirting violence in Turkey. In addition, the study is also thought to contribute to future studies on health communication as well as on interpersonal communication.

\section{Research Method}

The study was designed using the case study method. In the study, university students' views about whether parents' levels of education are influential on flirting violence were determined.

The study group included 250 students taking the face-to-face courses of psychology, developmental psychology, communication psychology, health communication and communication in family taught by the researcher at associate degree as well as at undergraduate and postgraduate degrees at Anadolu University in the academic year of 2016- 
2017. The questions used in the study were distributed to the students, and they were asked to respond to the questions on voluntary basis. Of all the students, 178 of them responded to the questions.

\section{Data Analysis and Findings}

This part presents not only the demographic information about the participants and their parents' levels of education but also the participants' responses to the question of "Do you think parents' levels of education trigger flirting violence within the socio-cultural structure?". The participants' responses can be seen in frequency Tables below. Also, the parents' levels of education and the question of "Do you think parents' levels of education trigger flirting violence within the socio-cultural structure?" were compared using Chisquare test.

\section{Findings Regarding the Demographic Data}

Table 1 presents the findings regarding the participants' ages.

Table1. Information about the Participants' Ages

Age

\begin{tabular}{l|l|l|l} 
Frequency & Percent & Valid Percent & Cumulative Percent
\end{tabular}

\begin{tabular}{rr|r|r|r|r}
\hline Valid & \multicolumn{1}{|c|}{2} & 1,1 & 1,1 & 1,1 \\
\hline 18 & 13 & 7,3 & 7,4 & 8,5 \\
\hline 20 & 21 & 11,8 & 11,9 & 20,5 \\
\hline 21 & 28 & 15,7 & 15,9 & 36,4 \\
\hline 22 & 27 & 15,2 & 15,3 & 51,7 \\
\hline 23 & 30 & 16,9 & 17,0 & 68,8 \\
\hline 24 & 20 & 11,2 & 11,4 & 80,1 \\
\hline 25 & 18 & 10,1 & 10,2 & 90,3 \\
\hline 26 & 5 & 2,8 & 2,8 & 93,2 \\
\hline 27 & 5 & 2,8 & 2,8 & 96,0 \\
\hline 28 & 2 & 1,1 & 1,1 & 97,2 \\
\hline 29 & 1 &, 6 &, 6 & 97,7 \\
\hline 30 & 2 & 1,1 & 1,1 & 98,9 \\
\hline
\end{tabular}




\begin{tabular}{ll|r|r|r|r}
\hline & 31 & 1,1 & 1,1 & 100,0 \\
\cline { 2 - 6 } & Total & 176 & 98,9 & 100,0 & \\
\hline Missing & System & 2 & 1,1 & & \\
\hline Total & 178 & 100,0 & & \\
\hline
\end{tabular}

Of all the participants responding to the questionnaire, $16,9 \%$ of them were 23 years old, and $0,6 \%$ of them were 28 years old.

Table 2 presents information about the participants' gender.

Table 2. Information about the Participants' Gender

\section{Gender}

\begin{tabular}{lr|r|r|r} 
& Frequency & Percent & Valid Percent & Cumulative Percent \\
\hline Valid & 2 & 1,0 & 1,0 & 1,0 \\
\cline { 2 - 6 } Male & 62 & 36 & 36 & 36 \\
\hline Femal & 114 & 64 & 64 & 100,0 \\
e & & & & \\
\hline Total & 178 & 100,0 & 100,0 & \\
\hline
\end{tabular}

Of all the participants responding to the questionnaire, $64 \%$ of them were female, while $36 \%$ of them were male.

Table 3 presents information about the students' levels of education.

Table 3. Participants' Levels of Education

\section{Education}

\begin{tabular}{ll|r|r|r|r} 
& Frequency & Percent & Valid Percent & Cumulative Percent \\
\hline Valid & 2 & 1,1 & 1,1 & 1,1 \\
\cline { 2 - 6 } & 153 & 86,0 & 86,0 & 87,1 \\
$\begin{array}{l}\text { Undergradua } \\
\text { te }\end{array}$ & & & & 95,5 \\
\hline $\begin{array}{l}\text { Postgraduate } \\
\text { Associate }\end{array}$ & 15 & 8,4 & 8,4 & 100,0 \\
Degree & 8 & 4,5 & 4,5 & \\
\hline
\end{tabular}


Of all the participants responding to the questionnaire, $89 \%$ of them were undergraduate students; $8,4 \%$ of them were postgraduate students; and $4,5 \%$ of them were students at an associate degree program.

Table 4 presents information about the participants' marital status.

Table 4. Participants' Marital Status

\section{Marital Status}

\begin{tabular}{lr|r|r|r} 
& Frequency & Percent & Valid Percent & Cumulative Percent \\
\hline Valid & 2 & 1,1 & 1,1 & 1,1 \\
\cline { 2 - 6 } Single & 173 & 97,2 & 97,2 & 98,3 \\
\hline Marrie & 3 & 1,7 & 1,7 & 100,0 \\
d & & & & \\
\hline Total & 178 & 100,0 & 100,0 & \\
\hline
\end{tabular}

Of all the participants responding to the questionnaire, $92 \%$ of them were single, while $1,7 \%$ of them were married.

Table 5 presents information about the participants' mothers' education level.

\section{Table 5. Participants' Mothers' Education Levels}

Mothers' Education Levels

\begin{tabular}{ll|r|r|r|r} 
& Frequency & Percent & Valid Percent & Cumulative Percent \\
\hline Valid & 3 & 1,7 & 1,7 & 1,7 \\
\cline { 2 - 5 } & $\begin{array}{l}\text { Elementary } \\
\text { School }\end{array}$ & 60 & 33,7 & 33,7 & 35,4 \\
\hline $\begin{array}{l}\text { Bachelor's } \\
\text { Degree }\end{array}$ & 38 & 21,3 & 21,3 & \\
\hline $\begin{array}{l}\text { Postgradua } \\
\text { te Degree }\end{array}$ & 4 & 2,2 & & 56,7 \\
\hline
\end{tabular}




\begin{tabular}{l|r|r|r|r}
\hline High & 69 & 38,8 & 38,8 & 97,8 \\
School & & & & \\
\hline Associate & 4 & 2,2 & 2,2 & 100,0 \\
Degree & & & & \\
\hline Total & 178 & 100,0 & 100,0 & \\
\hline
\end{tabular}

In the study, the participants' mothers had a high school degree $(38,8 \%)$, an elementary school degree $(33,7 \%)$, and a bachelor's degree $(21,3 \%)$.

Table 6 presents information about the participants' fathers' education level.

Table 6. Participants' Fathers' Education Levels

Fathers' Education Levels

\begin{tabular}{|c|c|c|c|c|c|}
\hline & & Frequency & Percent & Valid Percent & Cumulative Percent \\
\hline \multirow[t]{12}{*}{ Valid } & & 7 & 3,9 & 3,9 & 3,9 \\
\hline & Elementary & \multirow[t]{2}{*}{48} & \multirow[t]{2}{*}{27,0} & \multirow[t]{2}{*}{27,0} & \multirow[t]{2}{*}{30,9} \\
\hline & School & & & & \\
\hline & Bachelor's & \multirow[t]{2}{*}{51} & \multirow[t]{2}{*}{28,7} & \multirow[t]{2}{*}{28,7} & \multirow[t]{2}{*}{59,6} \\
\hline & Degree & & & & \\
\hline & Postgradua & \multirow[t]{2}{*}{5} & \multirow[t]{2}{*}{2,8} & \multirow[t]{2}{*}{2,8} & \multirow[t]{2}{*}{62,4} \\
\hline & te Degree & & & & \\
\hline & High & \multirow[t]{2}{*}{58} & \multirow[t]{2}{*}{32,6} & \multirow[t]{2}{*}{32,6} & \multirow[t]{2}{*}{94,9} \\
\hline & School & & & & \\
\hline & Associate & \multirow[t]{2}{*}{9} & \multirow[t]{2}{*}{5,1} & \multirow[t]{2}{*}{5,1} & \multirow[t]{2}{*}{100,0} \\
\hline & Degree & & & & \\
\hline & Total & 178 & 100,0 & 100,0 & \\
\hline
\end{tabular}

In the study, the participants' fathers had a high school degree $(32,6 \%)$, an associate degree $(28,7 \%)$, and an elementary school degree $(27 \%)$.

\section{Findings Regarding the Chi-Square Analysis}

In relation to the students' responses to the questionnaire, their views about whether parents' levels of education increase flirting violence were compared using the Chi-Square method. The students were asked to respond to the question of "Do you think parents' levels of 
education trigger flirting violence within the socio-cultural structure?" as "1-I Absolutely Agree, 2-I Agree, 3-I am Neutral, 4-I Disagree, 5-I Absolutely Disagree”. As for the parents' levels of education, the students were provided with the parameters of "1-Elementary School, 2-High School, 3-Associate Degree, 4-Bachelor's Degree, and 5-Postgraduate Degree”.

Table 7. Crosstab for Mothers' Education and the Question of "Do you think parents' levels of education trigger flirting violence within the socio-cultural structure?"

\begin{tabular}{|c|c|c|c|c|c|c|c|c|}
\hline & & & $\mathrm{S.4} * \mathrm{~S}$. & Crossta & lation & & & \\
\hline & & & & & S.7 & & & \\
\hline & & & 1 & 2 & 3 & 4 & 5 & Total \\
\hline S.4 & 1 & Count & 38 & 12 & 1 & 3 & 6 & 60 \\
\hline & & Expected Count & 37,0 & 13,0 & 1,7 & 2,1 & 6,2 & 60,0 \\
\hline & & \% within S.4 & $63,3 \%$ & $20,0 \%$ & $1,7 \%$ & $5,0 \%$ & $10,0 \%$ & $100,0 \%$ \\
\hline & & $\%$ within S.7 & $35,2 \%$ & $31,6 \%$ & $20,0 \%$ & $50,0 \%$ & $33,3 \%$ & $34,3 \%$ \\
\hline & 2 & Count & 43 & 15 & 2 & 2 & 7 & 69 \\
\hline & & Expected Count & 42,6 & 15,0 & 2,0 & 2,4 & 7,1 & 69,0 \\
\hline & & \% within S.4 & $62,3 \%$ & $21,7 \%$ & $2,9 \%$ & $2,9 \%$ & $10,1 \%$ & $100,0 \%$ \\
\hline & & \% within S.7 & $39,8 \%$ & $39,5 \%$ & $40,0 \%$ & $33,3 \%$ & $38,9 \%$ & $39,4 \%$ \\
\hline & 3 & Count & 2 & 1 & 1 & 0 & 0 & 4 \\
\hline & & Expected Count & 2,5 & 0,9 & 0,1 & 0,1 & 0,4 & 4,0 \\
\hline & & $\%$ within S.4 & $50,0 \%$ & $25,0 \%$ & $25,0 \%$ & $0,0 \%$ & $0,0 \%$ & $100,0 \%$ \\
\hline & & \% within S.7 & $1,9 \%$ & $2,6 \%$ & $20,0 \%$ & $0,0 \%$ & $0,0 \%$ & $2,3 \%$ \\
\hline & 4 & Count & 25 & 7 & 0 & 1 & 5 & 38 \\
\hline & & Expected Count & 23,5 & 8,3 & 1,1 & 1,3 & 3,9 & 38,0 \\
\hline & & \% within S.4 & $65,8 \%$ & $18,4 \%$ & $0,0 \%$ & $2,6 \%$ & $13,2 \%$ & $100,0 \%$ \\
\hline & & \% within S.7 & $23,1 \%$ & $18,4 \%$ & $0,0 \%$ & $16,7 \%$ & $27,8 \%$ & $21,7 \%$ \\
\hline & 5 & Count & 0 & 3 & 1 & 0 & 0 & 4 \\
\hline & & Expected Count & 2,5 & 0,9 & 0,1 & 0,1 & 0,4 & 4,0 \\
\hline & & $\%$ within S.4 & $0,0 \%$ & $75,0 \%$ & $25,0 \%$ & $0,0 \%$ & $0,0 \%$ & $100,0 \%$ \\
\hline & & \% within S.7 & $0,0 \%$ & $7,9 \%$ & $20,0 \%$ & $0,0 \%$ & $0,0 \%$ & $2,3 \%$ \\
\hline
\end{tabular}




\begin{tabular}{|l|r|r|r|r|r|r|}
\hline Total & 108 & 38 & 5 & 6 & 18 & 175 \\
\hline Expected Count & 108,0 & 38,0 & 5,0 & 6,0 & 18,0 & 175,0 \\
\hline \% within S.4 & $61,7 \%$ & $21,7 \%$ & $2,9 \%$ & $3,4 \%$ & $10,3 \%$ & $100,0 \%$ \\
\hline \% within S.7 & $100,0 \%$ & $100,0 \%$ & $100,0 \%$ & $100,0 \%$ & $100,0 \%$ & $100,0 \%$ \\
\hline
\end{tabular}

Table 8. Chi-Square Test for Mothers' Education and the Question of "Do you think parents' levels of education trigger flirting violence within the socio-cultural structure?"

\begin{tabular}{|c|c|c|c|}
\hline \multicolumn{4}{|c|}{ Chi-Square Tests } \\
\hline & Value & df & $\begin{array}{c}\text { Asymptotic Significance (2- } \\
\text { sided) }\end{array}$ \\
\hline Pearson Chi-Square & $25,290^{\mathrm{a}}$ & 16 & 0,065 \\
\hline Likelihood Ratio & 19,289 & 16 & 0,254 \\
\hline Linear-by-Linear Association & 0,081 & 1 & 0,776 \\
\hline $\mathrm{N}$ of Valid Cases & 175 & & \\
\hline
\end{tabular}

The crosstab and chi-square test tables for mothers' education and the question of "Do you think parents' levels of education trigger flirting violence within the socio-cultural structure?" can be seen above.

According to Table 8 which demonstrates the Chi-Square test results, there was no significant relationship between the mothers' education levels and the influence of parents' education levels on flirting violence as the Asymptotic Significance value was higher than $0,05(\mathrm{p}=$ $0,065>0,05)$ as shown by Pearson Chi-Square.

Table 9. Crosstab for Fathers' Education and the Question of "Do you think parents' levels of education trigger flirting violence within the socio-cultural structure?" 


\begin{tabular}{|c|c|c|c|c|c|c|c|}
\hline & & $\mathbf{S . 5} * \mathrm{~S}$ & 7 Crosst: & bulation & & & \\
\hline & & & & S.7 & & & \\
\hline & & 1 & 2 & 3 & 4 & 5 & Total \\
\hline S.5 1 & Count & 29 & 11 & 1 & 3 & 4 & 48 \\
\hline & Expected Count & 29,8 & 10,1 & 1,4 & 1,7 & 5,1 & 48,0 \\
\hline & $\%$ within S.5 & $60,4 \%$ & $22,9 \%$ & $2,1 \%$ & $6,3 \%$ & $8,3 \%$ & $100,0 \%$ \\
\hline & $\%$ within S.7 & $27,4 \%$ & $30,6 \%$ & $20,0 \%$ & $50,0 \%$ & $22,2 \%$ & $28,1 \%$ \\
\hline 2 & Count & 44 & 6 & 1 & 2 & 5 & 58 \\
\hline & Expected Count & 36,0 & 12,2 & 1,7 & 2,0 & 6,1 & 58,0 \\
\hline & $\%$ within S.5 & $75,9 \%$ & $10,3 \%$ & $1,7 \%$ & $3,4 \%$ & $8,6 \%$ & $100,0 \%$ \\
\hline & \% within S.7 & $41,5 \%$ & $16,7 \%$ & $20,0 \%$ & $33,3 \%$ & $27,8 \%$ & $33,9 \%$ \\
\hline 3 & Count & 3 & 2 & 1 & 0 & 3 & 9 \\
\hline & Expected Count & 5,6 & 1,9 & 0,3 & 0,3 & 0,9 & 9,0 \\
\hline & $\%$ within S.5 & $33,3 \%$ & $22,2 \%$ & $11,1 \%$ & $0,0 \%$ & $33,3 \%$ & $100,0 \%$ \\
\hline & \% within S.7 & $2,8 \%$ & $5,6 \%$ & $20,0 \%$ & $0,0 \%$ & $16,7 \%$ & $5,3 \%$ \\
\hline 4 & Count & 29 & 14 & 1 & 1 & 6 & 51 \\
\hline & Expected Count & 31,6 & 10,7 & 1,5 & 1,8 & 5,4 & 51,0 \\
\hline & \% within S.5 & $56,9 \%$ & $27,5 \%$ & $2,0 \%$ & $2,0 \%$ & $11,8 \%$ & $100,0 \%$ \\
\hline & \% within S.7 & $27,4 \%$ & $38,9 \%$ & $20,0 \%$ & $16,7 \%$ & $33,3 \%$ & $29,8 \%$ \\
\hline 5 & Count & 1 & 3 & 1 & 0 & 0 & 5 \\
\hline & Expected Count & 3,1 & 1,1 & 0,1 & 0,2 & 0,5 & 5,0 \\
\hline & $\%$ within S.5 & $20,0 \%$ & $60,0 \%$ & $20,0 \%$ & $0,0 \%$ & $0,0 \%$ & $100,0 \%$ \\
\hline & \% within S.7 & $0,9 \%$ & $8,3 \%$ & $20,0 \%$ & $0,0 \%$ & $0,0 \%$ & $2,9 \%$ \\
\hline Total & Count & 106 & 36 & 5 & 6 & 18 & 171 \\
\hline & Expected Count & 106,0 & 36,0 & 5,0 & 6,0 & 18,0 & 171,0 \\
\hline & $\%$ within S.5 & $62,0 \%$ & $21,1 \%$ & $2,9 \%$ & $3,5 \%$ & $10,5 \%$ & $100,0 \%$ \\
\hline & \% within S.7 & $100,0 \%$ & $100,0 \%$ & $100,0 \%$ & $100,0 \%$ & $100,0 \%$ & $100,0 \%$ \\
\hline
\end{tabular}

Table 10. Chi-Square Test for Fathers' Education and the Question of "Do you think parents' levels of education trigger flirting violence within the socio-cultural structure?" 


\begin{tabular}{|l|r|r|r|r|}
\hline \multicolumn{4}{|c|}{ Chi-Square Tests } \\
& Value & df & Asymptotic Significance (2-sided) \\
\hline Pearson Chi-Square & $27,437^{\text {a }}$ & 16 & 0,037 \\
Likelihood Ratio & 23,161 & 16 & 0,109 \\
Linear-by-Linear Association & 0,624 & 1 & 0,429 \\
& & & & \\
\hline N of Valid Cases & 171 & & \\
\hline a. 15 cells (60,0\%) have expected count less than 5. The minimum expected count is ,15. \\
\hline
\end{tabular}

The crosstab and chi-square test tables for fathers' education and the question of "Do you think parents' levels of education trigger flirting violence within the socio-cultural structure?" can be seen above. According to the Chi-Square test results presented in Table 10, there was a significant relationship between the fathers' education levels and the influence of parents' education levels on flirting violence as the Asymptotic Significance value was lower than $0,05(\mathrm{p}=0,065>0,05)$ as shown by Pearson Chi-Square.

\section{Discussion}

As is known, a number of factors within the socio-cultural structure influence violence generally and flirting violence specifically. The mothers of about three-fourth of the students participating in this study $(72,5 \%)$ had a high school degree at most, and this ratio was higher for the fathers. In a typical Turkish family, the mother, who has a second place in terms of power, spends more time and makes more efforts on bringing up the child when compared to the father. Therefore, in contrast to the related finding obtained in the study, the mother, who was found in the present study to have a higher average level of education, can be expected to have more influence on the child's attitudes and behaviors including the flirting violence. On the other hand, the finding that the father had more influence on the child could be regarded as the result of learning by doing. The reason is that it is generally the father who is dominant and who commits violence in the family. Based on the thought that children reflect what they witness or experience in their families, it could be stated that the students participating in the present study reported the father to be influential in terms of violence rather than the mother. 


\section{References}

Aslan D., Vefikuluçay, D., Zeyneloğlu, S., Erdost, T. andTemel, F. (2008). Ankara'da İki Hemşirelik Yüksekokulunun Birinci ve Dördüncü Sınıflarından Okuyan Öğrencilerinin Flört Şiddetine Maruz Kalma, Flört İlişkilerinde Şiddet Uygulama Durumlarının ve Bu Konudaki Görüşlerinin Saptanması Araştırması, Kadın Sorunları Araştırma Merkezi, Ankara: Hacettepe Üniversitesi.

Gökdağ R. (2017). Individual Acceptances Regarding Flirting Violance, International Symposium Communication in the Millenium, 16-19 May 2017, Irvine: University of California.

Özcebe, H., Aslan, D., Karabiber, A.H., Küçüköztaş, F., Oransay, K., Ölmez, İ. (2002). Bir Grup Üniversite Öğrencilerinin Flört Şiddeti Konusundaki Görüşleri, Toplum ve Sosyal Hizmet Dergisi, 13(1), 20-28.

Rosen, K. H. and Bezold, A. (1996). Dating Violence Prevention: A Didactic Support Group

For Young Woman, Journal of Counselling Developlent, 74(1), 521-525.

Tanrıverdi, G. and Şıpkın, S. (2008). Çanakkale'de Sağlık Ocaklarına Başvuran Kadınların

Eğitim Durumunun Şiddet Görme Düzeyine Etkisi, Fırat Tıp Dergisi, 13(3), 183-187. Yumuşak, A. veŞahin, R. (2014). Flörtte Şiddete Yönelik Tutum Ölçeklerinin Güvenirlik ve Geçerlik Çalışması, Elektronik Sosyal Bilimler Dergisi, 13(49), 233-252. 